\title{
Legal ecotones: A comparative analysis of riparian policy protection in the Oregon Coast Range, USA
}

*Brett A. Boisjolie ${ }^{\mathrm{a}}$, Mary V. Santelmann ${ }^{\mathrm{a}}$, Rebecca L. Flitcroft ${ }^{\mathrm{b}}$, Sally L. Duncan ${ }^{\mathrm{c}}$

${ }^{a}$ Oregon State University, College of Earth, Ocean, and Atmospheric Sciences, 104 CEOAS Administration Building, Corvallis, OR 97331, USA

*bboisjolie@gmail.com, corresponding author

santelmm@oregonstate.edu

${ }^{b}$ U.S. Forest Service, Pacific Northwest Research Station, 3200 SW Jefferson Way, Corvallis, OR 97331, USA

rflitcroft@fs.fed.us

' Oregon State University, Policy Analysis Laboratory, 302 Gilkey Hall, 122 SW Waldo Place, Corvallis, OR 97331, USA

sally.duncan@oregonstate.edu 


\begin{abstract}
Waterways of the USA are protected under the public trust doctrine, placing responsibility on the state to safeguard public resources for the benefit of current and future generations. This responsibility has led to the development of management standards for lands adjacent to streams. In the state of Oregon, policy protection for riparian areas varies by ownership (e.g., federal, state, or private), land use (e.g., forest, agriculture, rural residential, or urban) and stream attributes, creating varying standards for riparian land-management practices along the stream corridor. Here, we compare state and federal riparian land-management standards in four major policies that apply to private and public lands in the Oregon Coast Range. We use a standard template to categorize elements of policy protection: (1) the regulatory approach, (2) policy goals, (3) stream attributes, and (4) management standards. All four policies have similar goals for achieving water-quality standards, but differ in their regulatory approach. Plans for agricultural lands rely on outcome-based standards to treat pollution, in contrast with the prescriptive policy approaches for federal, state, and private forest lands, which set specific standards with the intent of preventing pollution. Policies also differ regarding the stream attributes considered when specifying management standards. Across all policies, 25 categories of unique standards are identified. Buffer widths vary from 0 to $\sim 152 \mathrm{~m}$, with no buffer requirements for streams in agricultural areas or small, non-fish-bearing, seasonal streams on private forest land; narrow buffer requirements for small, non-fish-bearing perennial streams on private forest land $(3 \mathrm{~m})$; and the widest buffer requirements for fish-bearing streams on federal land (two site-potential tree-heights, up to an estimated $152 \mathrm{~m}$ ). Results provide insight into how ecosystem concerns are addressed by variable policy approaches in multi-ownership landscapes, an important consideration to recovery-planning efforts for threatened species.
\end{abstract}

Keywords: land-management policy; public trust doctrine; riparian buffers; riverscapes 


\section{Introduction}

The legal doctrine of the public trust places responsibility on the state to safeguard public resources for the benefit of current and future generations. In the United States, the public trust doctrine is the fundamental justification for federal and state efforts to manage waterways, including water quality and quantity (Sax, 1970). The state is responsible for protecting the public interest in waterways and is charged with employing its inherent police powers to protect beneficial uses from interference by private actions (Johnson, 1988; Wilkinson, 1980; Wood, 2013). This has led to the creation of riparian land -management standards intended to mitigate the adverse effects of land use on water quality and aquatic ecosystems (Richardson et al., 2012). However, terrestrial environments are tied to historical private-property interests to use land (Cocklin et al., 2007; Rose, 1998; Wright and Czerniak, 2000). Requiring landowners to manage part of their land for environmental purposes reduces the land area available for agriculture, forest harvest, urbanization, or development, and thus could result in economic harm (Altshuler et al., 1993). This fundamental tension between public resources and private property defines riparian areas as "legal ecotones" encompassing fundamentally different legal ideologies with unclear boundaries. Hence, the creation of riparian land-management standards necessitates a balancing act between protecting public trust interests and maintaining certain historical privateproperty rights (Sax, 1971; Sinden, 2007). Due to inherent conflicts between use and protection, extending protective concern from waterways to land management can be highly controversial. Differing objectives for land management in different ownerships can influence the efficacy of protection measures at the scale of the river basin.

The public trust legal doctrine has been a component of common law since the time of the Romans, and has influenced resource management in national governments around the world 
(Craig, 2010). Resource protection and conservation is a fundamental element of governance (Hardin, 1968), and individual nations must make key decisions when establishing the priorities for protective efforts. Nations differ in the extent of state protection of terrestrial and aquatic resources. For example, France holds numerous resources in trust for public use, including rivers, streams, canals, and seacoasts, and extends these principles to terrestrial environments by placing limitations on ownership rights in forested areas. In Mexico, the property of common use is analogous to public trust protection, making navigable waters, fisheries, riverbanks, and forests common resources (Nanda and Ris, 1976). In the wake of water crises in the MurrayDarling Basin, Australia passed a series of reforms for water management which required development of Basin Plans for integrated water management (Kildea and Williams, 2010). The extent of public trust protection varies across countries, creating unique geographic contexts for exploring the balance between public and private interests. It may be of global interest to examine how these principles are applied through specific policy approaches intended to maintain ecosystem function, particularly across areas of diverse ownerships.

The individual states of the USA establish beneficial uses for the waterways held in trust, influencing the level of resource protection. Though beneficial-use designations vary by state, the public use of streams for commerce, navigation, and fishing is recognized across all states (Craig, 2010). The state of Oregon has adopted explicit public trust responsibilities in waterways, offering these systems the highest degree of protection (Morse v. Division of State Lands, 1979). In Oregon, protection of waterways is closely tied to protection of aquatic ecosystems. Public uses of riverine systems include the maintenance and enhancement of aquatic and fish life, thereby extending public trust protection to ecological values (ORS § 537.637). State responsibilities for maintaining, preserving, or recovering aquatic systems have become a 
primary mechanism for the adoption of standards guiding riparian land-management actions (ORS § 527.630(2)).

In the United States, federal regulatory efforts to maintain water quality and promote recovery of threatened species can further drive the development of riparian land-management standards. In particular, the Endangered Species Act of 1973 (ESA) and the Federal Water Pollution Control Amendments of 1972 (the Clean Water Act; CWA) link federal concerns with state management actions (Appendix Table 1A). The Endangered Species Act affects land management by prohibiting activities that may lead to the decline of at-risk species. The Clean Water Act mandates that states list the beneficial uses of their waterbodies and apply waterquality standards through narrative and numeric criteria specifying the acceptable levels of pollutants. In the state of Oregon, water-quality standards have established criteria for waterways to meet beneficial uses such as sustaining fish and aquatic life (Table 1). The federal listing of native Coho Salmon (Oncorhynchus kisutch) as a threatened species in the Oregon Coast Range added pressure for state agencies to adopt land-management standards that provided stream protection.

The waterways of the Oregon Coast Range have been the focus of management concern due to the great length of stream kilometers identified as water-quality limited, many based on sediment and stream temperature (Ice et al., 2004). As much as $43 \%$ of available stream habitat for Coho Salmon in the Oregon Coast Range has been identified as exceeding thermal tolerance limits (ODEQ, 2007). Water-quality concerns have resulted in greater scrutiny of existing landmanagement policies, including the regulation of activities in riparian areas (Richardson et al., 2012). However, conflicting perspectives and priorities for aquatic and terrestrial management objectives have led to a fragmented policy response, where standards vary based on ownership 
and land use (Johnson et al., 2007; Spies et al., 2007).

Although many studies have focused on the riparian-management policies of the region (Adams, 2007; Olson et al., 2007), few have thoroughly analyzed the variability of policy protection from a holistic riverscape perspective (Fausch et al., 2002; Flitcroft et al., 2014; Wiens, 2002), that assesses policy responses across ownerships and management entities. Our objective is to review and categorize elements of policy protection in riparian areas. In a similar review, Lee et al. (2004) focused on standards for private forest land across a large spatial extent, whereas our study seeks to fully categorize the variability of specific standards across ownerships and land uses in the specific area of the Oregon Coast Range. We incorporate a fine grain-size of policy analysis that allows for a continuous understanding of variable policy approaches across the region of interest. Categorizing policy protection clearly outlines the range of management standards that could be required for a given stream segment in the Oregon Coast Range. By understanding the range of current riparian-management standards and identifying those streams having limited policy protection, we hope to assist population-scale conservation efforts for threatened species such as Coho Salmon that require habitats throughout the river system to complete their life cycle (Groot and Margolis, 1991; Spies et al., 2007).

\section{Study Area}

For our area of analysis, we selected the Oregon Coast Range, delineated by the Oregon Coastal Coho Evolutionarily Significant Unit (ESU) for threatened Coho Salmon. The Oregon Coastal Coho ESU was designated by the National Oceanic and Atmospheric Administration (NOAA) as a distinct management region for the purposes of conservation and recovery of Coho Salmon after the species was listed as federally threatened under the Endangered Species Act 
(Weitkamp et al., 1995). The Oregon Coastal Coho ESU covers coastal drainages of western Oregon, extending from the mouth of the Columbia River south to Cape Blanco (Figure 1). With the exception of portions of the Umpqua River, which arise in the Cascade Range, rivers originate in the Oregon Coast Range. The Coast Range is characterized by considerable physical diversity, ranging from sand-dune systems to rocky outcrop high points. The geologic substrate is composed primarily of marine sandstones and shale, with some basaltic volcanic rock (Orr et al., 1992). Except for interior valleys and a few areas of coastal plain, the region is predominantly mountainous, with elevations of $0-1250 \mathrm{~m}$. The climate of this area is temperate maritime; precipitation occurs mostly from October to March, with cool, dry summers (Franklin and Dyrness, 1973). The forests of the Coast Range are highly productive, consisting of a mix of Douglas-fir (Pseudotsuga menziesii), western hemlock (Tsuga heterophylla), western redcedar (Thuja plicata), and Sitka spruce (Picea sitchensis). In addition to Coho Salmon, four other species of salmonids are found in the ESU, including Steelhead/Rainbow Trout (Oncorhynchus mykiss), Cutthroat Trout (O. clarkii), Chinook Salmon (O. tshawytscha), and Chum Salmon (O. keta). Resource-based industries such as agriculture and forestry have been important drivers of the regional economy for over a century, with associated long-term management effects evident in the distribution of stream habitats (Anlauf et al., 2011; Miller, 2010; Swanson and Lienkaemper, 1978)

\section{Methods}

We reviewed four major state and federal policies governing the management of riparian systems in the Oregon Coast Range to categorize the protective standards offered by each regulatory effort. Prominent land ownerships and land uses of the region include federal forests, 
state forests, private industrial and non-industrial forests, and agricultural lands. These ownerships are governed by riparian protections under the Northwest Forest Plan, State Forest Management Plans, the Oregon Forest Practices Administrative Rules, and Agricultural Water Quality Management Plans, respectively. Other important land use and ownership categories include urban areas, tribal lands, and lands owned by local jurisdictions. These ownerships have variable policies based on local decision-making, but represent a small proportion of land area $(<5 \%)$ in the Oregon Coast Range (ODFW, 2005) and were thus outside the scope of this analysis.

Here, we defined policy as the commitment of a group or agency to a particular course of action (Pielke, 2007). We categorized elements of policies using a modified taxonomy of policy measures similar to that of Cashore and Howlett (2007). We based this categorization on a content analysis of written documents related to riparian land-management policy. This included a policy review, a supplementary literature review, and personal correspondence with management agencies. Statutory laws, administrative rules and regulations, recovery plans, and regional plans were all examined, along with executive summaries, guidance documents, and other relevant agency briefs. To clarify important details and provide additional insights to inform the categorization process, we corresponded with agency professionals. The result was a comparative framework of policy protection across the major riparian-management policies (see also Lee et al., 2004).

First, we reviewed policies to establish the extent of their jurisdiction. We then categorized policies by elements of riparian policy protection, based on the regulatory approach, policy goals, stream context, and land-management standards of these policies. We defined regulatory approaches as outcome-based or prescriptive policies. Outcome-based policies rely on 
voluntary measures, - though standards can be applied if a pollutant repeatedly exceeds waterquality limits. Prescriptive policies create specific land-management standards intended to prevent water quality from deteriorating. Hence, prescriptive standards give more certainty of target condition, whereas outcome-based standards offer landowners leeway in management actions. We identified policy goals as the stated purpose of the policy effort. We were particularly interested in how many of these goals incorporate ecological concerns or focused specifically on state water-quality standards. In prescriptive policies, protective efforts are tailored to streams based on their context, determined by certain biophysical (e.g., fish use, streamflow duration, site-potential tree-height, mean annual flow, and material transport) and social (e.g., domestic water use) attributes. These attributes modify the land-management standards and buffer widths for streams subject to prescriptive policies. The stream context thus creates individual policy categories with unique management standards. These standards include fixed buffer widths, designated management areas, vegetation-retention guidelines, and other policy mechanisms.

\section{Results}

\subsection{Review of Riparian-Management Policies}

The Northwest Forest Plan (NWFP) was enacted to address habitat degradation on federal lands in the Pacific Northwest, including Bureau of Land Management and U.S. Forest Service lands (USDA and USDI, 1994). In the Oregon Coast Range, the plan covers an estimated 1052243 hectares (ha) of forest (ODFW, 2005), including the Siuslaw National Forest and portions of the Siskiyou and Umpqua National Forests. The NWFP establishes standards for federally-owned matrix lands managed for multiple purposes, including timber harvest and 
ecological conservation. The Plan contains an Aquatic Conservation Strategy (ACS) focused on management of stream systems and their riparian corridors. The riparian reserves element of the ACS sets buffer-width requirements for riparian land-management on public lands. Riparian reserves are defined as portions of the watershed most directly coupled to streams and rivers, including inner gorges, areas of riparian vegetation, the 100-year floodplain, and landslide-prone areas (USDA and USDI, 1994). The ACS prescribes interim widths for riparian reserves, with the intention that management standards could be adapted based on data from a watershed analysis. However, these interim buffer widths have remained intact in a majority of watersheds in the Oregon Coast Range due to complications in adopting more watershed-specific measures (Baker et al., 2005; Reeves et al., 2016).

The Oregon Coast Range contains an estimated 251787 ha of state forest land, including the Elliot, Tillamook, and Clatsop State Forests (ODFW, 2005). Management of state forests is guided by plans developed by the Oregon Department of Forestry, including two plans covering the Oregon Coast Range. Riparian standards for the Northwest State Forest Plan and the Southwest State Forest Plan are similar, using a blended management approach that encompasses a combination of landscape-level and site-specific strategies (ODF, 2010).

The Oregon Department of Forestry is also responsible for regulating industrial and nonindustrial private forest lands through the Forest Practices Administrative Rules (FPAR) (OAR § 629.600-670). These rules were created to fulfill a mandate in the Forest Practices Act (ORS § 527.610-992). This Act delegates authority for forest-practices rulemaking to the State Board of Forestry, a seven-member team appointed by the Governor of Oregon and confirmed by the State Senate (ODF, 2007). The board is responsible for developing and enforcing statewide and regional standards "in the public interest" (ORS § 527.630(2)). The Oregon Coast Range 
encompasses both the Coast Range and Interior regions, which have similar requirements for riparian land-management.

The Forest Practices Act applies to any commercial timber operation on private lands, covering an estimated 1051596 ha in the Oregon Coast Range (ODFW, 2005). Commercial timber operations are defined as "any commercial activity relating to the establishment, management, or harvest of forest tree species" (ORS § 527.620 (12)). Private use of timber and other land uses (e.g., orchards, Christmas tree farms) are exempt from designation as a timber operation, and are thus exempted from the standards of the act (Appendix Table 2A; Boisjolie 2016). A key component of the rules are the Water Protection Standards (OAR § 629.635), which specify vegetation-retention requirements along streams during timber harvest (OAR $\S$ 629.640). Operators who are in compliance with FPAR requirements are considered to be in compliance with Oregon's water-quality standards (ORS § 527.770).

Under federal pressure to limit water-quality degradation, the Oregon state legislature passed the Agricultural Water Quality Management Act (also known as Senate Bill 1010, ORS § 568.900-933). Through this act, the state delegated agricultural water-quality management to the Oregon Department of Agriculture (ODA). The department was charged with preventing and controlling water pollution resulting from agricultural activities (ORS § 568.900-933). ODA developed the Agricultural Water Quality Management Program, which divides the state into 38 management areas where local advisory committees develop area plans for water quality (ODA, 2012). The Oregon Coast Range includes six of these management areas: the Coos-Coquille, Curry, Mid-Coast, North Coast, Umpqua River, and Upper Willamette-Siuslaw. AgriculturalManagement Plans vary based on regional concerns for water quality and are reviewed every two years. These plans cover an estimated 380241 ha in the Oregon Coast Range (ODFW, 2005). 


\subsection{Regulatory Approach: Prescriptive vs. Outcome-based Policies}

A primary determinant of the level of policy protection in riparian areas is the regulatory approach used to meet policy goals. These regulatory approaches include prescriptive and outcome-based policies, as defined in section 3 above. Prescriptive policies set management standards intended to prevent pollution from occurring, whereas outcome-based policies are focused on treating pollution when it occurs. Regulatory approaches to riparian land management vary across our study area (Table 2).

In the Oregon Coast Range, a prescriptive regulatory approach is central to the Northwest Forest Plan, State Forest Management Plans, and the Oregon Forest Practices Administrative Rules. Under this approach, agencies create detailed rules specifying what is and is not allowed in land management. They give landowners specific guidelines for compliance and provide agencies with an enforceable standard. Prescriptive riparian-management policies often set fixed buffer widths within which some management actions are allowed and others are prohibited. Using a fixed-width approach, agencies specify target conditions in riparian corridors and apply these standards across large spatial extents. For example, governing agencies such as the Oregon Department of Forestry, the US Forest Service, and the US Bureau of Land Management apply prescriptive policies when they set specific standards for permissible management actions that landowners or agency managers are expected to follow.

Oregon’s Agricultural Water Quality Management Plans are outcome-based policies, which recommend Best Management Practices for agricultural land use and rely on voluntary adoption of these practices. An outcome-based approach does not prohibit or prescribe specific management activities or standards to landowners. Instead, agencies such as the Oregon 
Department of Agriculture (ODA) offer voluntary approaches to meet water-quality goals while leaving management decisions to individual landowners. Agency intervention occurs in cases of repeated violations of water-quality standards that can clearly be linked to a specific landowner (ODA, 2012). These plans give landowners discretion in their choice of the management actions taken to meet water-quality standards (OAR $\S 603-95-0020(2)$ ), and technical assistance is made available through local Soil and Water Conservation Districts.

\subsection{Policy Goals: The Purpose for Protection}

Comparison of the expressed purpose (goals) of the four major riparian-management policies offers insight into their specific objectives, and how these objectives vary across policies (Table 3). The Northwest Forest Plan and State Forest Management Plans - applied on public lands - focus on ecological processes and the development and maintenance of aquatic habitat. The Northwest Forest Plan includes short-term and long-term goals to address ecological concerns in the region. Goals incorporate emerging science, such as an emphasis on biodiversity, connectivity, and disturbance ecology. State Forest Management Plans also take responsibility for maintaining and restoring ecological function in riverscape systems. Goals include tying site standards to broader ecological processes within a policy framework.

The Forest Practices Administrative Rules and Agricultural Water Quality Management

Plans - applied on private lands — balance private interests (production of timber and agricultural commodities, economic development, jobs) with water-quality management objectives. As such, the goals of these policies emphasize the importance of riparian policies for meeting waterquality standards. The goals of the Forest Practices Administrative Rules note the function and value of natural resources. Water quality, hydrologic function, and resource harvest are the major 
priorities. The standards are intended to promote the development of mature tree stands along streams used by fishes. Management goals for non-fish-bearing streams focus on the influence of these areas on downstream fish-bearing waterways. Specific goals vary among the six Agricultural Water Quality Management Plans in the Oregon Coast Range based on regional water-quality concerns but all focus on mitigating the effects of land use to meet water-quality standards without mention of fish or wildlife resources or ecological processes.

\subsection{Stream Context: Different Stream Attributes, Different Standards}

The specific policy protections offered to riparian lands vary not only across policies, but also within policies. In an effort to tailor standards to a stream's context, regulators have developed requirements based on the stream's biophysical (fish-bearing, flow duration, sitepotential tree-height, stream size, and material transport potential) and social (domestic water use) attributes (Table 4). Policies differ in the attributes used for policy standard categorization (Figures 2-4). However, fish-bearing potential and streamflow duration (e.g., perennial or seasonal streams) are used in all three prescriptive policies.

The selection of stream attributes used to define applicable policy standards can reflect the intention of the policy. The Northwest Forest Plan, responding to political pressure to recover endangered species, employs a simple rubric that designates standards based on fish-bearing potential and duration of streamflow. The site-potential tree-height of a given site is used to determine the appropriate width for the riparian reserves, based on the average maximum height of the tallest dominant tree (200 years or older) for a given stream (FEMAT, 1993). This allows for a tailoring of standards based on broad biophysical concerns as well as site-based conditions. The State Forest Management Plan also considers the debris-flow transport potential for small, 
seasonal streams when designating riparian-management standards. This concern reflects the policy's emphasis on maintaining natural processes that contribute material important to the development of aquatic habitat. In addition to considering stream size, streamflow duration, and the potential to support fish, the Forest Practices Administrative Rules provide additional protective standards along streams where water is diverted for domestic uses. This is consistent with the policy's emphasis on maintaining water quality, as well as its attempt to balance social and economic interests in curbing some management actions to protect domestic water sources. Six individual Agricultural Water Quality Management Plans cover the area of the Oregon Coast Range (Figure 5), providing an opportunity for local policy action within different watersheds. Although these plans lack specific standards, their jurisdictional extent and local water-quality concerns create separate managing entities for agricultural lands across the Oregon Coast Range.

The use of stream attributes to set specific policy standards results in 19 prescriptive riparian policy categories with unique standards. In total, we identified 25 policy categories across the four policies. This excluded the option for a site-tailored prescription based on agency discretion, which is allowed in the prescriptive policies.

\subsection{Riparian Land-Management Standards: Requirements for Streamside Protection}

Standards are the established rules allowing or prohibiting management actions within riparian corridors. The management standards and width of these corridors varies across the four policies (Figure 6). The most restrictive standards apply to areas adjacent to the stream channel, with management restrictions decreasing with distance from the stream channel. Policies often employ a fixed buffer width for standard management prescriptions. Standards use a slope 
distance rather than a horizontal distance for these buffers, with exemptions for very steep streambanks (Oregon Forests Resources Institute, 2011).

The standards in the Northwest Forest Plan's Aquatic Conservation Strategy are by far the most precautionary (Appendix Table 3A). Interim widths for riparian reserves were established to afford the greatest level of protection, owing to the uncertainty of creating a protective policy response across a broad geographic extent (Reeves et al., 2016). Buffer widths for these reserves use a site-potential tree-height to establish management requirements, creating variability in reserve widths for similar stream types across watersheds. However, standards also include a minimum width for federal riparian areas across stream types. The upper extent of reserve widths included in Figure 6 (see also Appendix Table 4A) is based on data for mature trees in the Oregon Coast Range (Olson et al., 2007). At minimum, widths vary in the ACS from $30 \mathrm{~m}$ up to $91 \mathrm{~m}$, but can extend to $152 \mathrm{~m}$ based on the heights of the largest trees found in mature forests of the region.

Riparian protections under Oregon's State Forest Management Plans (Appendix Table 4A) are less precautionary than those of the NWFP. State Forest Management Plans divide riparian areas into four management zones with distinct requirements, where management actions are increasingly allowed with increased distance from the stream channel. The stream channel is defined as the aquatic zone. Within $7.5 \mathrm{~m}$ of the outer edge of the aquatic zone is the stream-bank zone, where no timber harvest is allowed. Adjacent to the stream-bank zone is an area defined as the riparian management area (RMA), which extends to $52 \mathrm{~m}$ from the stream channel. Within RMAs, an inner and an outer zone are specified, where required site conditions are specified based on proximity to the stream channel. The inner RMA extends from the stream bank $30 \mathrm{~m}$ upslope, with the outer RMA extending from $30 \mathrm{~m}$ to $52 \mathrm{~m}$ distances from the stream 
channel. The outer RMA is less restrictive in its requirements, creating a gradient of management restrictions extending outward from the stream channel in both directions.

Although State Forest Management Plans have established similar buffer widths for many of the streams on state forests, the land-management standards for the RMAs vary considerably across stream types. For example, fish-bearing streams are offered high levels of protection up to $30 \mathrm{~m}$ from the channel, and minimal management is allowed between $30 \mathrm{~m}$ and $52 \mathrm{~m}$ from the channel. Inner and outer RMAs for non-fish-bearing streams are far more permissive in management actions, and are variable across stream types. Standards are most permissive for non-fish-bearing streams of small size or seasonal flow.

Of the three prescriptive riparian-management policies, the Forest Practices Administrative Rules have the least restrictive standards (Appendix Table 5A), particularly for small, non-fish-bearing streams. The Forest Practices Administrative Rules establish RMAs that are not divided into two zones. Standards are tailored to stream context in this policy (Figure 4). For example, fish-bearing streams are subcategorized based on stream size, with narrower buffers applied to smaller streams. Large streams have slightly more restrictive standards compared with medium and small streams. Few standards are in place for small, non-fishbearing streams, and no standards restrict activity around small, seasonal, non-fish-bearing streams without domestic water use.

The Forest Practices set target basal areas in RMAs, defined as the total cross-sectional area of all tree stems in a stand (Oregon Forest Resources Institute, 2011). If basal area can be achieved in less than the established width, RMA widths may be reduced. The rules also allow for alternative prescriptions in the event of disturbance [OAR § 629-640-0300 (3)], or in areas dominated by hardwoods [OAR § 629-640-0300 (4)]. They also allow for site-specific standards 
developed by operators [OAR § 629-640-0400], dependent on these plans' ability to achieve vegetation-retention goals [OAR § 629-640-0000].

Agricultural water-quality management plans do not set specific standards based on stream context, but the Oregon Department of Agriculture (ODA) has responsibility for ensuring that agricultural lands are in compliance with water-quality standards. Because of this, ODA has discretion to develop land-management standards for agricultural areas. The trigger for development and regulatory enforcement of these standards is a violation of water-quality standards (ORS § 568.912(2)). The ODA uses enforcement only when necessary to gain compliance with agricultural water-quality regulations. These compliance actions are complaintdriven, and include investigations and correspondence before a civil penalty is issued.

\section{Discussion}

Our review of riparian policy protection in the Oregon Coast Range highlights the variability in standards that exist across riverscapes of diverse ownerships and land-use practices. The application of land-management policies based on ownership creates unique management implications for state public trust responsibilities to protect aquatic ecosystems and preserve water quality. Federal and state agencies develop standards that reflect the balancing act between land- and water-management objectives, resulting in the differing levels of policy protection reviewed here. Current policy variability results in widths of mandated vegetation retention ranging from $0 \mathrm{~m}$ in agricultural areas and on non-fish-bearing small streams under the Forest Practices Administrative Rules, to two site-potential tree-heights (upwards of $\sim 152 \mathrm{~m}$ ) on fishbearing streams under the Northwest Forest Plan. Understanding this variability provides a frame of reference for characterizing a multi-agency policy response to ecosystems concern. This range 
of variability gives context to broader considerations of public trust responsibilities occurring across nations, as each faces similar decisions regarding the state's responsibility to protect resources.

The differences in the two regulatory approaches reviewed here (prescriptive and outcome-based standards) are important to consider when managing dynamic ecosystems. Prescriptive and outcome-based regulatory approaches implement land-management standards in fundamentally different ways - the former sets standards to prevent pollution whereas the latter is a regulatory tool used to treat pollution when other means fail. In the Oregon Coast Range, the efficacy of the existing outcome-based approach has been questioned. Recently, the National Oceanic and Atmospheric Administration and the Environmental Protection Agency rejected the non-point-source pollution plan of the State of Oregon (NOAA and USEPA, 2015). The agencies focused on both the minimal riparian-management standards on private lands as well as the current strategy for agricultural land regulation, citing numerous elements of the outcome-based approach that have thus far made it insufficient to prevent water-quality degradation. These concerns have been echoed in the recent recovery plans for coastal Coho Salmon, which cite the potential of agricultural actions to degrade salmon habitat and the lack of riparian criteria to prevent deleterious effects of land use (NMFS, 2016). Because agricultural areas are leading sources of water-quality impairments on rivers across the nation (USEPA, 2000), concerns arise that this regulatory approach is misaligned with the effects of that land use (Houck, 1999; Williams, 2002).

The efficacy of outcome-based policy approaches can be difficult to assess. The reliance on voluntary measures and lack of specific standards can lead to uncertainties in riverscape-scale planning and recovery efforts. Linking downstream water-quality exceedances to a specific 
parcel of land can be problematic, often necessitating extensive monitoring with the possibility of inconclusive results (Dowd et al., 2008; Kaushal et al., 2011). It is also difficult to establish the cumulative effects of individual voluntary actions on a riverscape (ODA, 2012). This has led to the development of methods to help incentivize the implementation of riparian conditions that are likely to prevent pollution, including the development of watershed councils committed to working with private landowners. Watershed-based efforts that include incentives can allow innovative landowners the opportunity to create riparian conditions appropriate to an individual stream reach while minimizing conflict. However, ensuring riverscape-scale function requires substantial financial resources and broad support throughout the watershed for management practices that protect aquatic systems.

Although prescriptive approaches can be effective policy mechanisms for limiting pollution (Cole and Grossman, 1999), concerns also exist regarding these traditional policy efforts. The appropriate use of prescriptive standards is the subject of a great deal of discussion, particularly as policy frameworks evolves to incorporate continuously emerging scientific understanding of natural disturbances and ecological processes (Allen et al., 2011; Craig, 2010; Reeves et al., 1995). The "command and control" approach, setting a target state for ecological conditions that in reality vary across time and space, represents a conceptual model in which policy efforts are used to constrain management practices based on an idea of the "proper" target condition for ecosystems (Hollings and Meffe, 1996). Although prescriptive policy approaches can create a simple standard of enforcement (Richardson et al., 2012; Wagner, 2000), attempts to constrain ecosystems states to meet "ideal" conditions can be difficult, costly, and ill-suited to the dynamic nature of aquatic ecosystems in time and space (Reeves et al., 1995, 2016). It is a major challenge to develop protective policy approaches that maintain continuity in ecological 
processes while allowing for inherent variability in ecological conditions (Newton and Ice, 2015). Such an approach would necessitate a balancing of the tools in the regulatory toolbox, involving careful coordination and planning across agencies to allow for reach-scale tailoring of standards while ensuring broader riverscape-scale processes.

A key factor that influences the range of variability both across and within policies is the level of protection given based on stream context - the product of both biophysical and social considerations. For example, standards for buffer widths on federal lands can vary by up to 120 $\mathrm{m}$ based on fish-bearing potential, streamflow duration, and the site-potential tree-height. Fishbearing streams are consistently offered the greatest policy protection across the three prescriptive policy approaches, with more restrictive standards on perennial streams compared to seasonal streams. The matrix of stream attributes used to categorize policy standards, often combined with a checkerboard ownership pattern in the Oregon Coast Range, results in a policy response in which standards can fluctuate significantly from stream segment to stream segment.

Of the prescriptive policy approaches, we found the fewest protective standards on private lands adjacent to small, non-fish-bearing streams. Small, non-fish-bearing streams often comprise a large percentage of the total stream length in coastal watersheds (Gomi et al., 2005) and have significant influence on fish-bearing reaches downstream (Groom et al., 2011; Kirkby, 2013). They are also ecologically important for regional plant and animal biodiversity and riparian-dependent species (Olson et al., 2007). There are ongoing concerns for the minimal policy protection on these streams, with many questions regarding the cumulative effects of policy measures on water quality across the riverscapes of the Oregon Coast Range (Frissell, 2014; NOAA and USEPA, 2015; Welsh, 2000). Although the Forest Practices Administrative Rules set buffer widths of 0-6 m for non-fish-bearing streams, comparable streams are assigned 
buffer widths of 30-76 m on federal lands, and restrictive standards apply up to $30 \mathrm{~m}$ (with lessrestrictive standards up to $52 \mathrm{~m}$ ) for similar streams on state lands. The Oregon Board of Forestry voted to revise riparian-management standards in November 2015, but revisions applied only to large and medium salmon, steelhead, and Bull Trout (Salvelinus confluentus) streams and did not include any changes for non-fish-bearing streams (ODF, 2015). Due to the uncertainty of effects and efficacy, the differences in standards offered to non-fish-bearing streams will likely continue to be a source of debate.

At multiple spatial extents, ecosystems can be influenced by policy drivers that act to constrain the variability of ecosystems. Thus the range of variability across policy approaches can influence habitat conditions in time and space (Duncan et al., 2010; Reeves and Duncan, 2009). These policies establish thresholds of interference with historical land uses, dictate the extent to which historical natural disturbances are allowed on a landscape (e.g., debris flows, fires, material transport, among others), and define the ability of a landscape to support heterogeneity of conditions. The variability in protective standards across policies and thus also across landscapes has strong implications for connected protection of riparian corridors at riverscape scales of management (e.g., watershed councils, recovery planning, conservation networks, and other collaborative efforts).

This question of variability is linked to the unique legal and political geographies of a given spatial extent. We were able to characterize this variability across the Oregon Coast Range, finding a specific range in protective metrics such as fixed-width buffers (Figure 6). Although the Pacific Northwestern United States has a complicated array of riparian standards, boreal regions in Canada have been found to have wider buffer widths, whereas the southeastern United States has simple guidelines for narrow buffer widths across stream types (Lee et al., 2004). 
Examination of riparian-management standards across countries reveals further examples of different systems of policy protection for riparian systems (Naiman et al., 2010). One example is the Ibrahaim River in Lebanon, a historically significant river system protected by buffer zones of $500 \mathrm{~m}$ (Makhzoumi and Abboud, 2005). In the European Union, the Habitats Directive crreated "special areas of conservation," including several riparian community types, that aspire to balance conservation efforts with societal demands on riparian systems (EU, 1999).

Central to the variability of specific land-management standards is the broader legal context of the public trust doctrine and state responsibilities for resource protection. Our study region allows us to review and explore how the public trust balancing act plays out in a multiownership landscape with an approach evolving toward ecological management. Individual legal and policy contexts, and the analysis of management policies that emerge in those contexts, can help inform emerging paradigms for the management of dynamic ecosystems. In the USA beyond Oregon, other states have begun to expand the public trust concept so that legal protection is concerned not only with the status of resources such as air, water, and species, but also with the interactions of these resources across ecosystems, resulting in an emerging "ecological public trust" (Craig, 2010). Examples include Hawaii, citing its reliance on natural resources as an island ecosystem, and California, citing the scarcity of water resources: each state has begun adopting broader public trust responsibilities. Public trust concepts have also been suggested as a possible legal avenue for climate change adaptation efforts at the national level (Craig, 2009). Collectively, the emergence of public trust resource protection across nations can foster international cooperation on environmental protection (Nanda and Ris, 1976). The concept may continue to develop as a powerful tool for global action, uniting efforts to protect resources for present and future generation all around our planet. 


\section{Acknowledgements}

We thank the agency personnel who assisted in the review process by clarifying concepts, providing feedback, and checking details. Kathryn Ronnenberg and Kelly Christiansen provided important support for graphics, table format, and editorial review. The U.S. Department of Agriculture Forest Service provided funding and support for the analytical portion of the project. Finally, we thank the editor of the journal and the anonymous reviewers whose comments and suggestions improved the manuscript.

\section{References}

Adams, P.W., 2007. Policy and management for headwater streams in the Pacific Northwest: synthesis and reflection. Forest Sci. 53, 104-118.

Allen, C.R., Cumming, G.S., Garmestani, A.S., Taylor, P.D., Walker, B.H., 2011. Managing for resilience. Wildlife Biol. 17, 337-349.

Altshuler, A.A., Gomez-Ibanez, J.A., Howitt, A.M., 1993. Regulation for revenue: The political economy of land use exactions. Lincoln Institute for Land Policy, Cambridge, Massachusetts, 1-175.

Anlauf, K.J., Jensen, D.W., Burnett, K.M., Steel, E.A., Christiansen, K., Firman, J.C., Feist, B.E., Larsen, D.P., 2011. Explaining spatial variability in stream habitats using both natural and management-influenced landscape predictors. Aquat. Conserv. 21, 704-714.

Baker, D., Ferguson, G., Palmer, C., Tolle, T., 2005. Northwest Forest Plan-The first 10 years (1994-2003): Implementation monitoring: Summary of regional interagency monitoring results. Tech. Paper R6-RPM-TP-04-2005. U.S. Department of Agriculture, Pacific 
Northwest Region, Portland, OR. http://www.reo.gov/monitoring/reports/10yrreport/implementation/CPImpleMoniFirstTenYears1-23-06.pdf (accessed 31-07-2016).

Boisjolie, B.A., 2016. Policy Patterns across Riverscapes: Riparian Land Standards in the Oregon Coast Range. M.S. thesis. Oregon State University, Corvallis, OR.

Cashore, B., Howlett, M., 2007. Punctuating which equilibrium? Understanding thermostatic policy dynamics in Pacific Northwest forestry. Am. J. Polit. Sci. 51, 532-551.

Clean Water Act of 1972, 33 U.S.C. § 1251 et seq.

Cocklin, C., Mautner, N., Dibden, J., 2007. Public policy, private landholders: Perspectives on policy mechanisms for sustainable land management. J. Environ. Manage. 85, 986-998.

Cole, D.H., Grossman, P.Z., 1999. When is command-and-control efficient-institutions, technology, and the comparative efficiency of alternative regulatory regimes for environmental protection? Wisc. Law Rev. 887-938.

Craig, R.K., 2009. Adapting to climate change: The potential role of state common-law Public Trust Doctrines. Vt. Law Rev. 34, 781-854.

Craig, R.K., 2010. A comparative guide to the western states' public trust doctrines: Public values, private rights, and the evolution toward an ecological public trust. Fla. St. U. Law Rev. 369, 53-197.

Dowd, B.M., Press, D., Los Huertos, M., 2008. Agricultural nonpoint source water pollution policy: The case of California's central coast. Agr. Ecosyst. Environ. 128, 151-161.

Duncan, S.L., McComb, B.C., Johnson, K.N., 2010. Integrating ecological and social ranges of variability in conservation of biodiversity: Past, present, and future. Ecol. Soc., 15.

Endangered Species Act of 1973, 16 U.S.C. $§ 1531$ et seq 
EU (European Union), 1999. Interpretation manual of European Union habitats. European Commission EUR 15/2. Brussels, Belguim.

Fausch, K.D., Torgersen, C.E., Baxter, C.V., Li, H.W., 2002. Landscapes to riverscapes: bridging the gap between research and conservation of stream fishes. BioScience 52, 483-498.

FEMAT (Forest Ecosystem Management Assessment Team), 1993. Forest ecosystem management: An ecological, economic, and social assessment. Report of the Forest Ecosystem Management Assessment Team. U.S. Government Printing Office, Washington, D.C.

Flitcroft, R., Burnett, K., Snyder, J., Reeves, G., Ganio, L., 2014. Riverscape patterns among years of juvenile coho salmon in midcoastal Oregon: implications for conservation. T. Am. Fish. Soc. 143, 26-38.

Franklin, J.F., Dyrness, C.T., 1973. Natural vegetation of Oregon and Washington. General Technical Report PNW-8. U.S. Department of Agriculture, Forest Service, Pacific Northwest Forest and Range Experiment Station, Portland, OR.

Frissell, C.A., 2014. Declaration of Christopher A. Frissell, Ph. D. In Support of the U.S. Environmental Protection Agency's and the National Oceanic and Atmospheric Administration's proposal to disapprove the State of Oregon's Coastal Nonpoint Pollution Control Program for failing to adopt additional management measures for forestry. Northwestern Environmental Advocates. http://northwestenvironmentaladvocates.org/blog/wp-content/uploads/2014/03/ Declaration-of-Christopher-Frissell-3-14-14.pdf (accessed 22-07-2016). 
Gomi, T., Moore, R D., Hassan, M.A., 2005. Suspended sediment dynamics in small forest streams of the Pacific Northwest. J. Am. Water Resour. As. 41, 877-898.

Groom, J.D., Dent, L., Madsen, L.J., Fleuret, J., 2011. Response of western Oregon (USA) stream temperatures to contemporary forest management. Forest Ecol. Manag. 262, $1618-1629$.

Groot, C., Margolis, L., 1991. Pacific Salmon Life Histories. UBC Press, Vancouver, B.C.

Hardin, G., 1968. The Tragedy of the Commons. Science 162, 1243-1248.

Holling, C.S., Meffe, G.K., 1996. Command and control and the pathology of natural resource management. Conserv. Biol. 10, 328-337.

Houck, O., 1999. The Clean Water Act TMDL Program: Law, Policy, and Implementation. Environmental Law Institute, Washington, D.C.

Ice, G.G., Light, J., Reiter, M., 2004. Use of natural temperature patterns to identify achievable stream temperature criteria for forest streams. West. J. Appl. For. 19, 252-259.

Johnson, K.N., Bettinger, P., Kline, J.D., Spies, T.A., Lennette, M., Lettman, G., Garber-Yonts, B., Larsen T., 2007. Simulating forest structure, timber production, and socioeconomic effects in a multi-owner province. Ecol. Appl. 17, 34-47.

Johnson, R.W., 1988. Water pollution and the public trust doctrine. Envtl. L. 19, 485-513.

Kaushal, S.S., Groffman, P.M., Band, L.E., Elliott, E.M., Shields, C.A., Kendall, C., 2011. Tracking nonpoint source nitrogen pollution in human-impacted watersheds. Environ. Sci. Technol. 45, 8225-8232.

Kildea, P., Williams, G., 2010. The Constitution and the management of water in Australia's rivers Sydney Law Review Vol. 32: 595-616. 
Kirkby, K.S., 2013. Distribution of juvenile salmonids and stream habitat relative to 15-year-old debris-flow deposits in the Oregon Coast Range. M.S. thesis. Oregon State University, Corvallis, OR.

Lee, P., Smyth, C., Boutin, S., 2004. Quantitative review of riparian buffer width guidelines from Canada and the United States. J. Environ. Manage. 70: 165-180.

Makhzoumi, J., Abboud, M., 2005. The multifunctional landscape of the Ibrahim River, Lebanon. In: Naiman, R.J, Décamps, H., McClain, M.E. (eds). Riparia: Ecology, Conservation, and Management of Streamside Communities. Elsevier Academic Press, Burlington, MA.

Miller, R.R., 2010. Is the past present? Historical splash dam mapping and stream disturbance detection in the Oregon Coast Range. M.S. thesis. Oregon State University, Corvallis, OR.

Morse v. Division of State Lands, 1979. 581 P.2d 520, 524 (Or. Ct. App. 1978, aff'd, 590 P.2d 709).

Naiman, R. J., Décamps, H., McClain, M. E., 2010. Riparia: Ecology, Conservation, and Management of Streamside Communities. Elsevier Academic Press, Burlington, MA.

Nanda, V.P., Ris, W.R., 1976. Public trust doctrine: A viable approach to international environmental protection. Ecol. Law Quart. 5, 291-319.

Newton, M., Ice, G., 2015. Regulating riparian forests for aquatic productivity in the Pacific Northwest, USA: Addressing a paradox. Environ. Sci. Pollut. R. 23, 1149-1157.

NMFS (National Marine Fisheries Service), 2016. 5-Year Review: Summary \& Evaluation of Oregon Coast Coho Salmon. West Coast Region, Portland, OR. 
NOAA and USEPA (National Oceanic and Atmospheric Administration and United States Environmental Protection Agency), 2015. NOAA/EPA Finding That Oregon Has Not Submitted A Fully Approvable Nonpoint Program. NOAA, Washington, D.C.

Olson, D.H., Anderson, P.D., Frissell, C.A., Welsh, H H., Bradford, D.F., 2007. Biodiversity management approaches for stream-riparian areas: Perspectives for Pacific Northwest headwater forests, microclimates, and amphibians. For. Ecol. Manag. 246, 81-107.

OAR (Oregon Administrative Rules) http://sos.oregon.gov/archives/Pages/oregon_administrative_rules.aspx (accessed 22-07-2016)

ODA (Oregon Department of Agriculture), 2012. Oregon Agricultural Water Quality Report. Salem, OR. https://www.oregon.gov/ODA/shared/Documents/Publications/ NaturalResources/ORAgWaterQualityReport.pdf (accessed 03-08-2016).

ODEQ (Oregon Department of Environmental Quality), 2007. Water quality assessment: Oregon's 2004/2006 integrated report. Report 406. Salem, OR.

ODFW (Oregon Department of Fish and Wildlife), 2005. Land Use/Ownership - Coastal Coho ESU. ODFW. Salem, OR.

ODF (Oregon Department of Forestry), 2007. Forest Practices Rule Guidance - Water Protection Rules. ODF, Salem, OR.

ODF (Oregon Department of Forestry), 2010. Final Oregon State Forests Management Plan [Northwest and Southwest]. ODF, Salem, OR.

ODF (Oregon Department of Forestry), 2015. November 5, 2015 Board of Forestry Streamside Buffer (Riparian) Rule Analysis Decision. ODF, Salem, OR. 
http://www.oregon.gov/ODF/Documents/WorkingForests/RiparianRule20151 109.pdf (accessed 22-07-2016)

Oregon Forest Resources Institute, 2011. Oregon's Forest Protection Laws: Second Edition. Adams, P.W., and Storm, R. (eds). Portland, OR http://knowyourforest.org/ (accessed 22-07-2016)

ORS (Oregon Revised Statutes) https://www.oregonlegislature.gov/bills_laws/Pages/ORS.aspx (accessed 22-07-2016)

Orr, E.L., Orr, W.N., Baldwin, E.M., 1992. Geology of Oregon. 4th ed. Kendal V Hunt Publishing Company, Dubuque, Iowa.

Pielke, R.A., 2007. The Honest Broker: Making Sense of Science in Policy and Politics. Cambridge University Press, Cambridge, UK.

Reeves, G.H., Benda, L.E., Burnett, K.M., Bisson, P.A., Sedell, J.R., 1995. A disturbance based ecosystem approach to maintaining and restoring freshwater habitats of evolutionarily significant units of anadromous salmonids in the Pacific Northwest Trans. Am. Fish. S. Suppl. 17, 334-349.

Reeves, G.H., Duncan, S.L., 2009. Ecological history vs. social expectations: managing aquatic ecosystems. Ecol. Soc. 14, 8.

Reeves, G.H., Pickard, B.R., Johnson, K.N., 2016. An initial evaluation of potential options for managing riparian reserves of the Aquatic Conservation Strategy of the Northwest Forest Plan. U.S. Department of Agriculture, Forest Service, Pacific Northwest Research Station, Portland, OR. 
Richardson, J.S., Naiman, R.J., Bisson, P.A., 2012. How did fixed-width buffers become standard practice for protecting freshwaters and their riparian areas from forest harvest practices? Freshw. Sci. 31, 232-238.

Rose, C.M., 1998. Joseph Sax and the idea of the public trust. Ecol. Law Quart. 25, 351-362.

Sax, J.L., 1970. The public trust doctrine in natural resource law: Effective judicial intervention. Mich. Law Rev. 68, 471-566.

Sax, J.L., 1971. Takings, private property and public rights. Yale Law J., 81, 149-186.

Sinden, A., 2007. Tragedy of the Commons and the myth of private property solution, Univ. Colo. Law Rev. 78, 533.

Spies, T.A., Johnson, K.N., Burnett, K.M., Ohmann, J. L., McComb, B.C., Reeves, G.H., Bettinger, P., Kline, J.D., Garber-Yonts, B., 2007. Cumulative ecological and socioeconomic effects of forest policies in coastal Oregon. Ecol. Appl. 17, 5-17.

Swanson, F.J., Lienkaemper, G.W., 1978. Physical consequences of large organic debris in Pacific Northwest streams. General Technical Report PNW-69. U.S. Department of Agriculture, Forest Service, Pacific Northwest Research Station, Portland, OR.

U.S.C. (United States Code), https://www.gpo.gov/fdsys/browse/collectionUScode.action?collectionCode=USCODE (accessed 22-07-2016)

USDA and USDI (US Department of Agriculture and US Department of the Interior), 1994. Record of decision for amendments to Forest Service and Bureau of Land Management planning documents within the range of the northern spotted owl [plus Attachment A: Standards and Guides]. [Place of publication unknown]: US Department of Agriculture and US Department of the Interior. http://www.reo.gov/library/reports/newroda.pdf 
USEPA (US Environmental Protection Agency), 2000. Atlas of America's Polluted Waters. EPA 840-B00-002. Office of Water, Washington, D.C.

Wagner, W.E., 2000. The triumph of technology-based standards. U. Illinois Law Rev. 83-113.

Weitkamp, L., Wainwright, T., Bryant, G., Milner, G., Teel, D., Kope, R., Waples, R., 1995. Status review of coho salmon from Washington, Oregon, and California. NOAA Tech. Memo, NMFS-NWFSC-24. U.S. Department of Commerce, Washington, D.C.

Welsh, H.H., Jr., Roelofs, T.D., Frissell, C.A., 2000. Aquatic ecosystems of the redwood region. In: Noss, R.F. (Ed.), The Redwood Forest: History, Ecology, and Conservation of the Coast Redwoods. Island Press, Covelo, CA, 165-199.

Wiens, J.A., 2002. Riverine landscapes: Taking landscape ecology into the water. Freshwater Biol. 47, 501-515.

Wilkinson, C.F., 1980. The public trust doctrine in public land law. U.C. Davis L. Rev. 14, 269316.

Williams, D.R., 2002. When voluntary, incentive-based controls fail: Structuring a regulatory response to agricultural nonpoint source water pollution. Wash. J. Envtl. L. \& Pol'y. 21, $21-121$.

Wood, M.C., 2013. Nature's trust: Environmental law for a new ecological age. Cambridge University Press, Cambridge, U.K.

Wright, J.B., Czerniak, R.J., 2000. The rising importance of voluntary methods of land use control in planning. J. Plan. Educ. Res. 19, 419-423. 


\section{Figure Captions}

Figure 1: Spatial extent and applicable jurisdictions of the various riparian land-management policies in the Oregon Coastal Range, for areas located in the Oregon Coastal Coho Salmon Evolutionarily Significant Unit.

Figure 2. Categorization of riparian-management policy standards in the federal Northwest Forest Plan.

Figure 3. Categorization of riparian-management policy standards in Oregon State Forest Management Plans.

Figure 4. Categorization of riparian-management policy standards in Oregon Forest Practices Administrative Rules for private forest lands.

Figure 5. Categorization of riparian-management policy standards in Agricultural Water Quality Management Plans for private agricultural lands.

Figure 6. Designated widths for riparian buffers in the Oregon Coast Range. These widths extend from both sides of a stream. 
Table 1. Oregon Water Quality Standards applicable to the protection of stream biota

\begin{tabular}{|c|c|c|}
\hline Policy & Purpose & Actions \\
\hline $\begin{array}{l}\text { Oregon State Water } \\
\text { Quality Standards } \\
\text { (OAR } § 340-041- \\
\text { 0028) }\end{array}$ & $\begin{array}{l}\text { "..to protect, maintain and improve } \\
\text { the quality of the waters of the state } \\
\text { for public water supplies, for the } \\
\text { propagation of wildlife, fish and } \\
\text { aquatic life and for domestic, } \\
\text { agricultural, industrial, municipal, } \\
\text { recreational and other legitimate } \\
\text { beneficial uses" (ORS } \S \\
\text { 468B.015(2)). }\end{array}$ & $\begin{array}{l}\text { - Oregon has ten designated beneficial uses for its streams, } \\
\text { including fish and aquatic life. } \\
\text { - Waters shall be of sufficient quality to support aquatic species } \\
\text { without detrimental changes in the resident biological } \\
\text { communities (OAR } \S 340-41-027) \text {. } \\
\text { - Salmon migration corridor streams have a temperature standard } \\
\text { of } 20^{\circ} \mathrm{C} \text {, salmon and trout rearing streams have an } 18^{\circ} \mathrm{C} \\
\text { temperature standard, and a } 13^{\circ} \mathrm{C} \text { threshold is established for } \\
\text { salmonid spawning, egg incubation, and fry emergence (OAR } \S \\
340-041-0028-4 \mathrm{c}) \text {. } \\
\text { - Streams containing cold-water pockets are required to maintain } \\
\text { temperatures below } 16^{\circ} \mathrm{C} \text { based on a seven-day-average } \\
\text { maximum temperature (OAR } \S 340-041-0028-4(\mathrm{~b}) \text { ). } \\
\text { - Human activity cannot result in temperature increases }>0.3{ }^{\circ} \mathrm{C} \text { in } \\
\text { any waterway supporting cool-water species or in waters } \\
\text { determined to be ecologically significant to cold-water holdings } \\
\text { (OAR } \S 340-041-0028-11(\text { a)). This includes waterbodies } \\
\text { supplying cold water to downstream reaches supporting cold- } \\
\text { water biota (OAR } \S 340-041-0006 \text { (57)). } \\
\text { - Standards for erosion and sedimentation in aquatic systems are } \\
\text { narrative. Sediment cannot be detrimental to fish, aquatic life, } \\
\text { public health, recreation, or industry (OAR } \S 340-21(\text { basin)( } 2)(\mathrm{j}) \text { ). } \\
\text { - Numeric standards for turbidity are based on a relative } \\
\text { benchmark. Management operations occurring persistently cannot } \\
\text { result in a greater than } 10 \% \text { increase in turbidity (OAR } \S 340-41- \\
\text { (basin)(2)(c)). }\end{array}$ \\
\hline
\end{tabular}


Table 2. Regulatory approach of riparian-management policies in the Oregon Coast Range.

\begin{tabular}{|c|c|c|}
\hline Policy & Ownership and land use & Regulatory approach \\
\hline $\begin{array}{l}\text { Northwest Forest Plan } \\
\text { - Aquatic Conservation Strategy }\end{array}$ & Federal forests & Prescriptive \\
\hline Oregon State Forest Management Plans & State forests & Prescriptive \\
\hline $\begin{array}{l}\text { Forest Practices Administrative Rules } \\
\text { - Water Protection Rules }\end{array}$ & $\begin{array}{l}\text { Private industrial and non- } \\
\text { industrial forests }\end{array}$ & Prescriptive \\
\hline Agricultural Water Quality Management Plans & Private agricultural lands & Outcome-based \\
\hline
\end{tabular}


Table 3. Purpose and goals of the riparian-management policies of the Oregon Coast Range

\begin{tabular}{|c|c|c|}
\hline Policy & Purpose & Goals \\
\hline $\begin{array}{l}\text { Northwest } \\
\text { Forest Plan - } \\
\text { Aquatic } \\
\text { Conservation } \\
\text { Strategy } \\
\text { (USDA and } \\
\text { USDI, 1994) }\end{array}$ & $\begin{array}{l}\text { Maintain and restore ecosystem } \\
\text { health at watershed and landscape } \\
\text { scales as well as protect fish and } \\
\text { riparian habitat. Goals are tied to } \\
\text { promoting the restoration of } \\
\text { landscape-scale processes. At } \\
\text { project levels, management actions } \\
\text { must not adversely affect or retard } \\
\text { attainment of standards at the } \\
\text { watershed scale. }\end{array}$ & $\begin{array}{l}\text { - Short-term goal (10-20 years): Halt declines in watershed } \\
\text { condition and protect watersheds containing high-quality } \\
\text { water, habitat, and healthy fish populations. } \\
\text { - Long-term goal (100+ years): Develop a network of } \\
\text { functioning watersheds that support populations of fish } \\
\text { and other aquatic and riparian-dependent organisms } \\
\text { across the NWFP area. } \\
\text { - Other stated goals include maintaining riparian structure } \\
\text { and function, managing for riparian-dependent species, } \\
\text { enhancing habitat conservation in riparian-upslope } \\
\text { ecotones, and creating greater connectivity within } \\
\text { watersheds. }\end{array}$ \\
\hline $\begin{array}{l}\text { Oregon State } \\
\text { Forest } \\
\text { Management } \\
\text { Plans (ODF, } \\
2010)\end{array}$ & $\begin{array}{l}\text { Maintain or restore key ecological } \\
\text { functions of aquatic, riparian, and } \\
\text { upland areas that directly influence } \\
\text { the freshwater habitat of aquatic } \\
\text { species, within the context of the } \\
\text { natural disturbance regimes that } \\
\text { create habitat for these species. } \\
\text { Providing diverse aquatic and } \\
\text { riparian conditions over time and }\end{array}$ & $\begin{array}{l}\text { - The goal for fish-bearing and larger non-fish-bearing } \\
\text { streams is to grow and retain vegetation so that, over } \\
\text { time, riparian and aquatic habitat conditions become } \\
\text { similar to those associated with mature forest stands. } \\
\text { - The goal for small non-fish-bearing streams is to grow } \\
\text { and retain vegetation sufficient to support the functions } \\
\text { and processes identified as important, and to contribute to } \\
\text { properly functioning conditions in downstream fish- } \\
\text { bearing streams. }\end{array}$ \\
\hline
\end{tabular}
space would more closely emulate the natural disturbance regime under which native species evolved. 


\begin{tabular}{|c|c|c|}
\hline Policy & Purpose & Goals \\
\hline $\begin{array}{l}\text { Forest } \\
\text { Practices } \\
\text { Administrative } \\
\text { Rules_- Water } \\
\text { Protection } \\
\text { Rules (OAR § } \\
629.600-670 \text { ) }\end{array}$ & $\begin{array}{l}\text { "...to protect, maintain and, where } \\
\text { appropriate, improve the functions } \\
\text { and values of streams, lakes, } \\
\text { wetlands, and riparian management } \\
\text { areas...these functions and values } \\
\text { include water quality, hydrologic } \\
\text { function, the growing and harvesting } \\
\text { of trees, and fish and wildlife } \\
\text { resources" (OAR §629-635-0100 } \\
\text { (3)) }\end{array}$ & $\begin{array}{l}\text { - “...To provide resource protection during operations } \\
\text { adjacent to and within streams, lakes, wetlands, and } \\
\text { riparian management areas so that, while continuing to } \\
\text { grow and harvest trees, the protection goals for fish, } \\
\text { wildlife, and water quality are met" (OAR } § 629-635 \text { - } \\
0100(7) \text { ). } \\
\text { "[The goal] along fish use streams is to grow and retain } \\
\text { vegetation so that, over time, average conditions across } \\
\text { the landscape become similar to those of mature } \\
\text { streamside stands" (OAR } \S 629-640-0000(2) \text { ). } \\
\text { "[The goal] for streamside areas that do not have fish use } \\
\text { is to have sufficient streamside vegetation to support the } \\
\text { functions and processes that are important to downstream } \\
\text { fish use waters and domestic water use and to supplement } \\
\text { wildlife habitat across the landscape" (OAR } \S 629-640- \\
\text { 000). }\end{array}$ \\
\hline $\begin{array}{l}\text { Agricultural } \\
\text { Water Quality } \\
\text { Management } \\
\text { Plans (ORS } \S \\
568.900-933 \text { ) }\end{array}$ & $\begin{array}{l}\text { Carry out a plan for the prevention } \\
\text { and control of water pollution from } \\
\text { agricultural activities and soil } \\
\text { erosion, based on scientific } \\
\text { information }\end{array}$ & $\begin{array}{l}\text { - To prevent and control water pollution from agricultural } \\
\text { activities and soil erosion and to achieve applicable } \\
\text { water-quality standards } \\
\text { - Specific goals vary based on individual water-quality } \\
\text { concerns within each of the } 6 \text { plans. The aim for the } \\
\text { establishment and development of riparian vegetation is } \\
\text { to provide sufficient riparian function including shade, } \\
\text { streambank integrity, and filtration of nutrients/sediment. }\end{array}$ \\
\hline
\end{tabular}


Table 4. Definition of stream attributes used to categorize riparian-management standards

\begin{tabular}{|c|c|c|}
\hline $\begin{array}{c}\text { Stream } \\
\text { attribute }\end{array}$ & Categories & Definition \\
\hline \multirow[t]{2}{*}{ Fish-bearing } & Fish & $\begin{array}{l}\text {-Any stream used by anadromous fish, game fish, or } \\
\text { fish listed as threatened or endangered under the } \\
\text { federal or state Endangered Species Acts (ODF, 2010) } \\
\text { - Fish use can be seasonal or year round (ODF, 1994) } \\
\text { - Fish use exists to the first natural barrier to fish use, } \\
\text { unless there is pre-2007 classification of non-fish } \\
\text { upstream of an artificial obstruction (ODF, 2007) }\end{array}$ \\
\hline & Non-fish-bearing & $\begin{array}{l}\text { - Waters that are not designated as fish-bearing (ODF, } \\
\text { 2010) }\end{array}$ \\
\hline \multirow[t]{2}{*}{$\begin{array}{l}\text { Streamflow } \\
\text { duration }\end{array}$} & Perennial & $\begin{array}{l}\text { - Streams that are expected to have summer surface } \\
\text { flow after July 15th (ODF, 2010) }\end{array}$ \\
\hline & Seasonal & $\begin{array}{l}\text { - Streams that flow only during portions of the year; } \\
\text { these streams are not expected to have summer } \\
\text { surface flow after July 15th (ODF, 2010) } \\
\text { - Nonpermanent flowing drainage feature having 1) } \\
\text { definable channel and 2) evidence of annual scour or } \\
\text { deposition (also categorized as: seasonal, intermittent, } \\
\text { ephemeral) - (USDA and USDI, 1994) }\end{array}$ \\
\hline \multirow[t]{4}{*}{ Stream size } & & $\begin{array}{l}\text { - Calculated using a relationship based on upstream } \\
\text { drainage area and annual precipitation (ODF, 1994) }\end{array}$ \\
\hline & Small & - Average annual flow of $0.06 \mathrm{cms}$ or less (ODF, 2010) \\
\hline & Medium & $\begin{array}{l}\text { - Average annual flow greater than } 0.06 \mathrm{cms} \text {, less than } \\
0.54 \mathrm{cms}(\mathrm{ODF}, 2010)\end{array}$ \\
\hline & Large & $\begin{array}{l}\text { - Average annual flow of } 0.54 \mathrm{cms} \text { or greater (ODF, } \\
\text { 2010) }\end{array}$ \\
\hline
\end{tabular}




\begin{tabular}{|c|c|c|}
\hline $\begin{array}{c}\text { Stream } \\
\text { attribute }\end{array}$ & Categories & Definition \\
\hline \multirow[t]{2}{*}{$\begin{array}{l}\text { Domestic } \\
\text { water use }\end{array}$} & Domestic use & $\begin{array}{l}\text { - Streams located upstream of any domestic water } \\
\text { intake for which a water use permit has been issued } \\
\text { by the Oregon Water Resources Department (Oregon } \\
\text { Department of Forestry, 1994) } \\
\text { - Classification extends upstream from the point of } \\
\text { diversion to the shortest of following distance: 1) The } \\
\text { distance upstream from the intake to the farthest } \\
\text { upstream point of summer surface flow; } 2 \text { ) Half the } \\
\text { distance from the intake to the drainage boundary; or } \\
\text { 3) } 91.4 \text { m upstream from the intake (ODF, 1994) } \\
\text { - Uses can include domestic, group domestic, quasi- } \\
\text { municipal, or municipal water uses. Specific rules } \\
\text { apply to community water systems (ODF, 2007b) }\end{array}$ \\
\hline & No domestic use & $\begin{array}{l}\text { - Streams that are not designated as having domestic } \\
\text { water use }\end{array}$ \\
\hline \multirow[t]{3}{*}{$\begin{array}{l}\text { Material } \\
\text { transport } \\
\text { potential }\end{array}$} & $\begin{array}{l}\text { Seasonal high } \\
\text { energy streams }\end{array}$ & $\begin{array}{l}\text { - Seasonal streams with physical conditions that favor } \\
\text { the periodic transport of coarse sediments and woody } \\
\text { materials during high flow events } \\
\text { - Stream reaches with an average gradient exceeding } \\
15 \% \text { and an active channel width of } 1.5 \text { m or greater } \\
\text { (ODF, 2010) }\end{array}$ \\
\hline & $\begin{array}{l}\text { Potential debris } \\
\text { flow track } \\
\text { reaches }\end{array}$ & $\begin{array}{l}\text { - Reaches determined to have high probability of } \\
\text { delivering large woody debris to a fish-bearing stream } \\
\text { (ODF, 2010) }\end{array}$ \\
\hline & Other & $\begin{array}{l}\text { - Small seasonal streams that are not designated high } \\
\text { energy or potential debris flow track (ODF, 2010) }\end{array}$ \\
\hline
\end{tabular}


Figure 1: Spatial extent and applicable jurisdictions of the various riparian land-management policies in the Oregon Coast Range, for areas located within the Oregon Coastal Coho Salmon Evolutionarily Significant Unit.

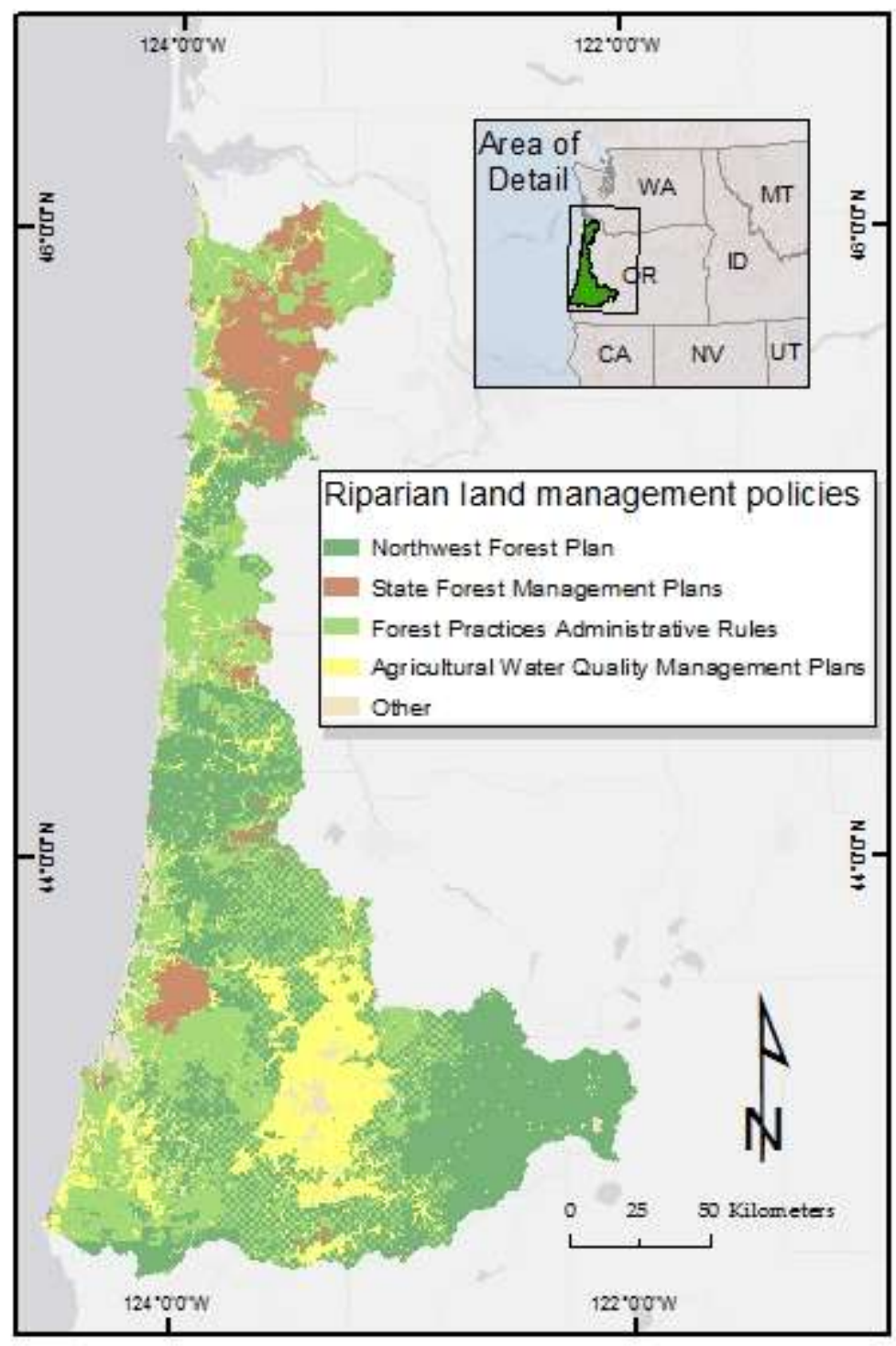


Figure 2. Categorization of riparian-management policy standards in the federal Northwest Forest Plan.

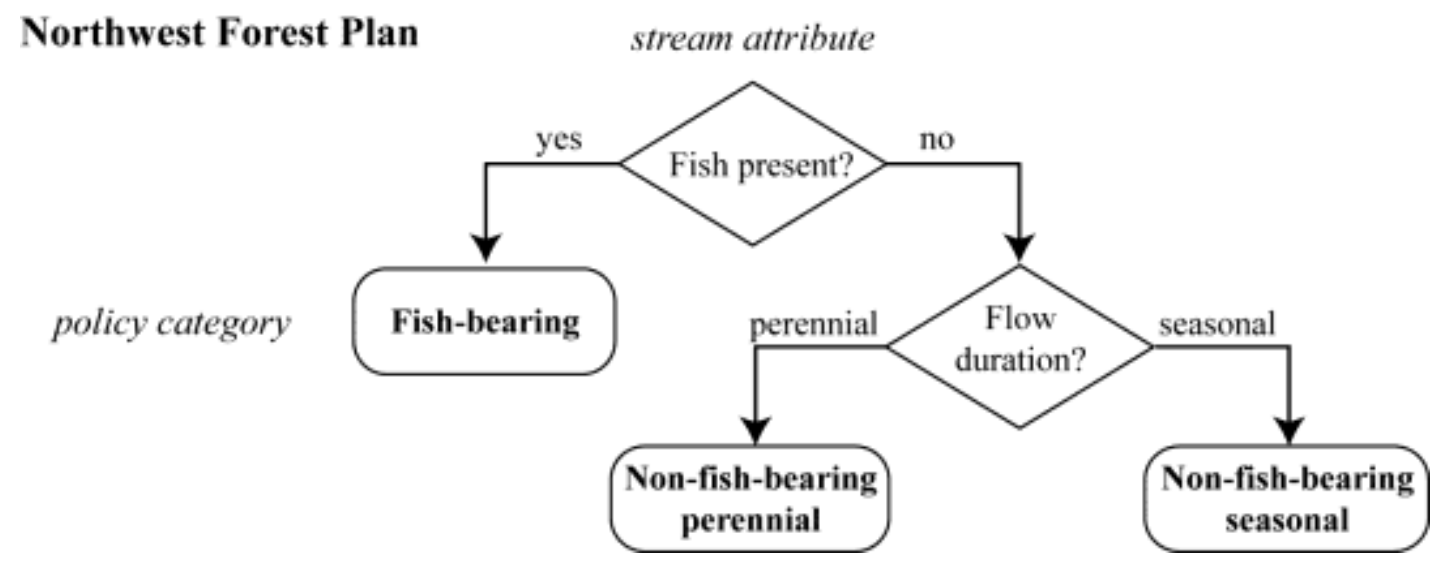


Figure 3. Categorization of riparian-management policy standards in Oregon State Forest Management Plans.

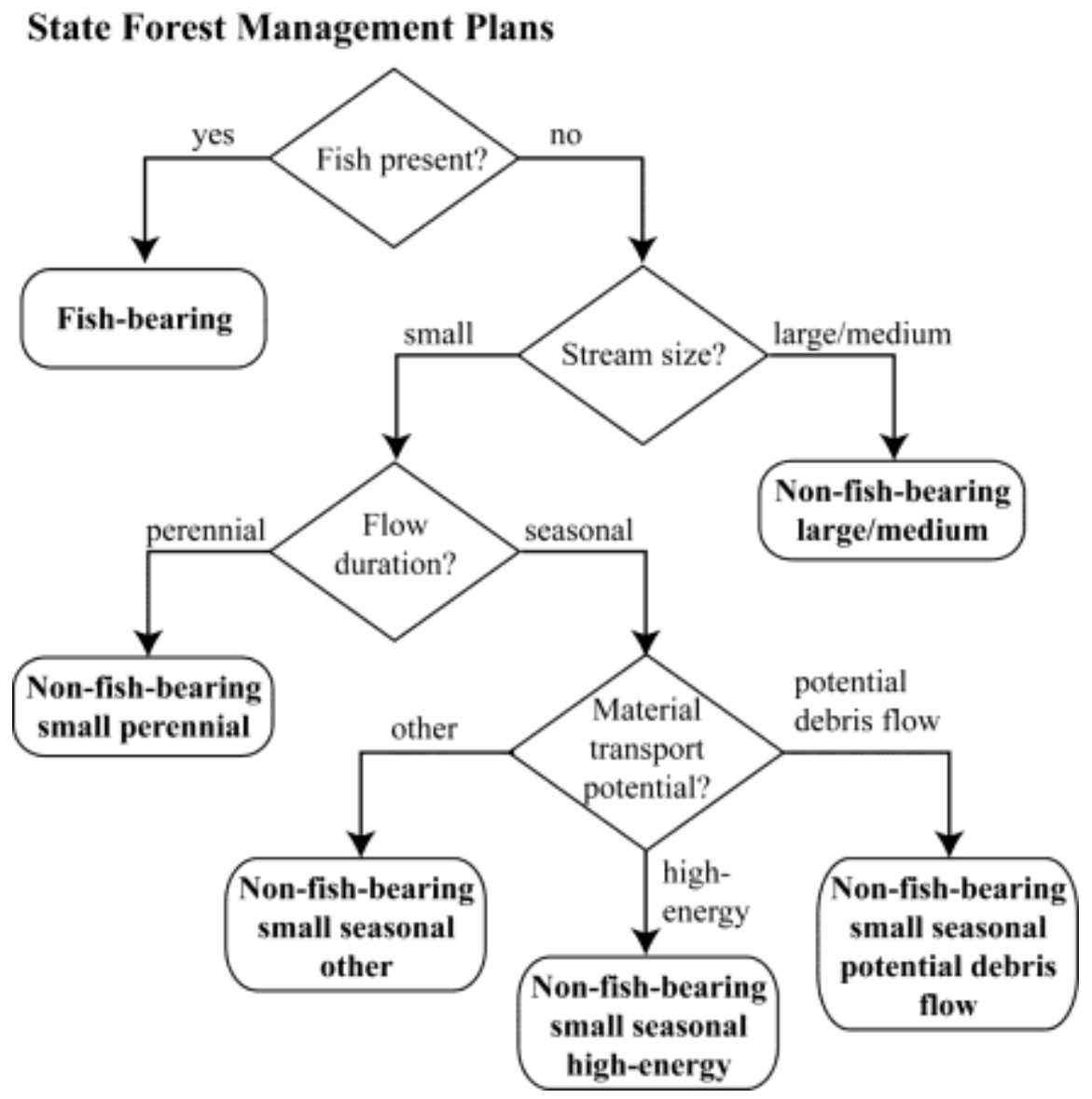


Figure 4. Categorization of riparian-management policy standards in Forest Practices Administrative Rules for private forest lands.

\section{Forest Practices Administrative Rules}

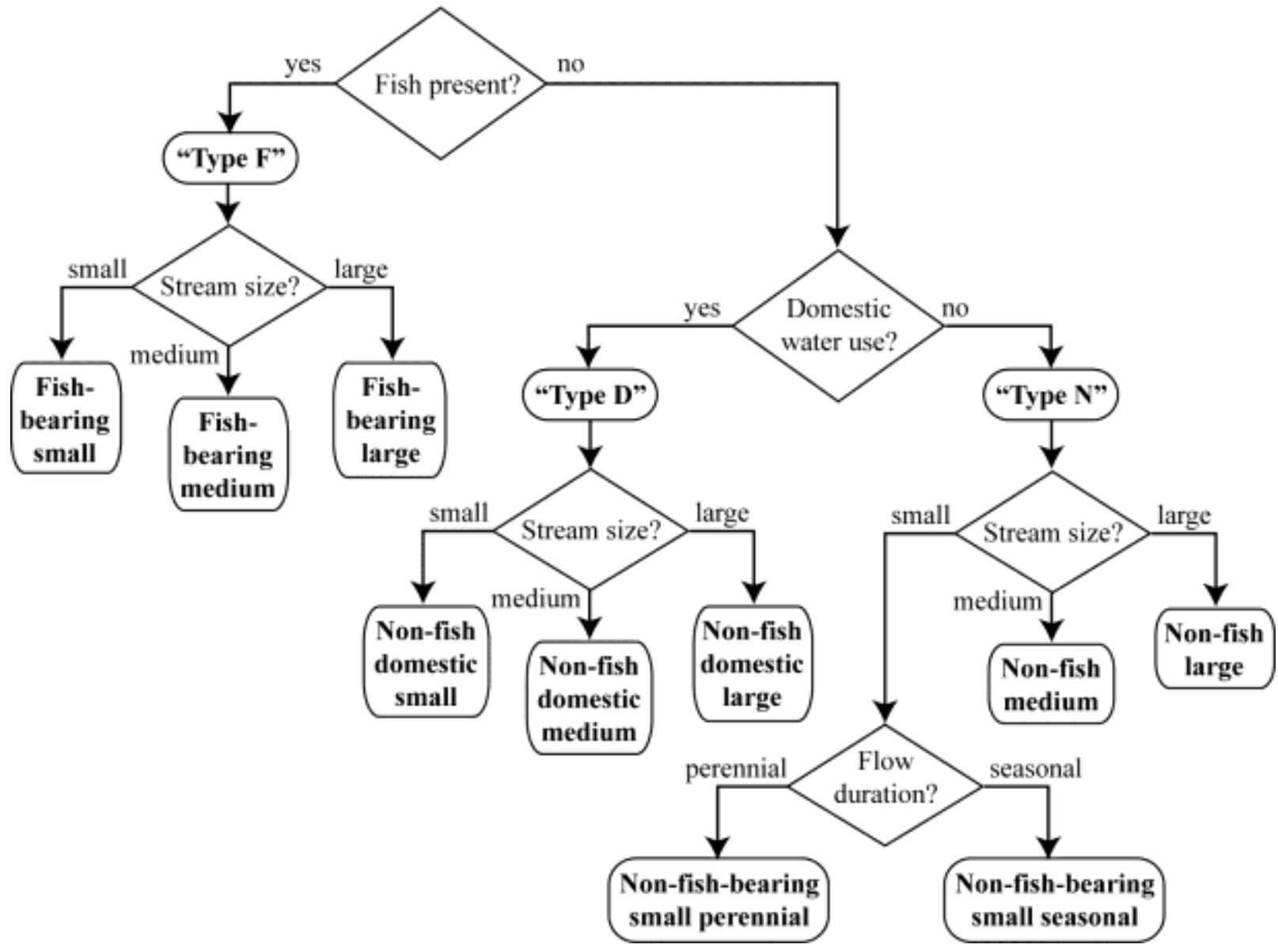


Figure 5. Categorization of riparian-management policy standards in Agricultural Water Quality Management Plans for private agricultural land.

\section{Agricultural Water Quality Management Plans}

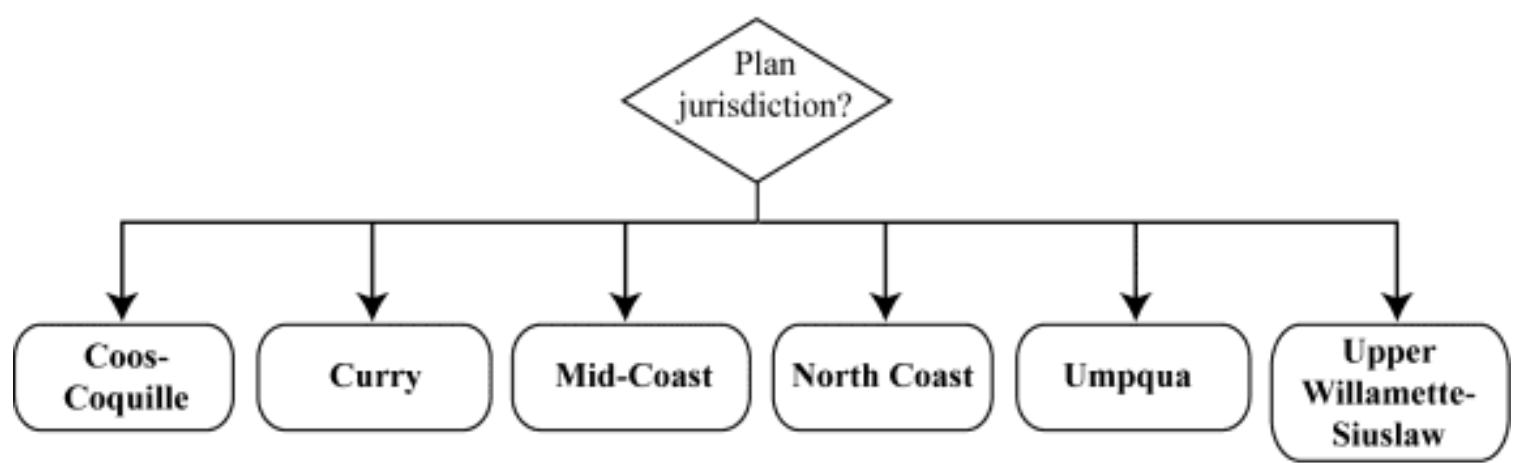

Plans address relevant concerns regarding: algae or aquatic weeds, bacteria, chlorophyll a, dissolved oxygen, habitat modification, $\mathrm{pH}$, sediment, turbidity, temperature, waste management, mercury and toxins. 
Figure 6. Designated widths for riparian buffers in the Oregon Coast Range. These widths extend from both sides of a stream.

\section{Riparian Management Buffers in the Oregon Coast Range}

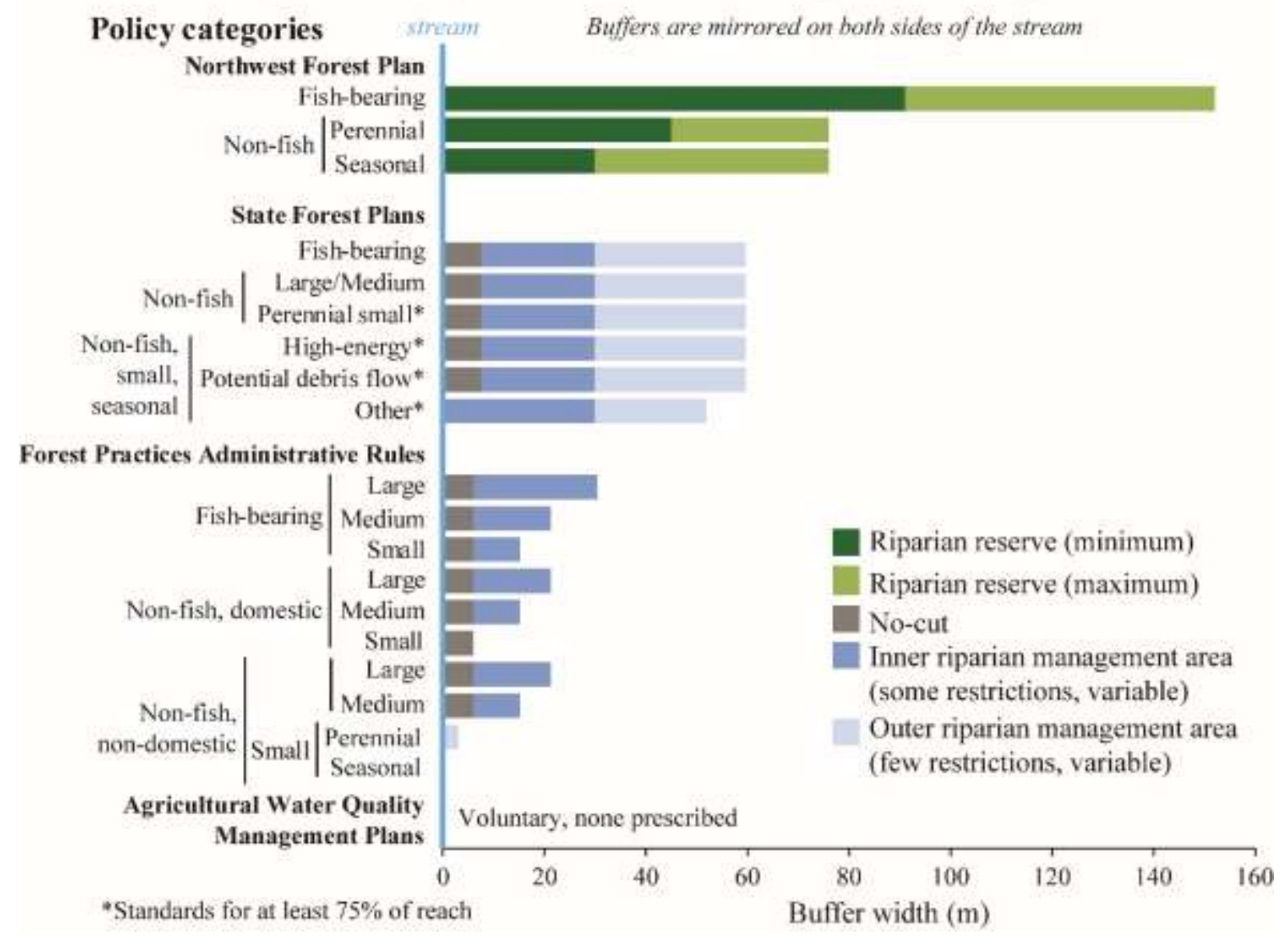




\section{Appendix}

Table 1A. Federal policy mechanisms for the creation of riparian-management standards.

\begin{tabular}{|c|c|c|}
\hline Policy & Purpose & Actions \\
\hline $\begin{array}{l}\text { Clean Water Act } \\
\text { (33 U.S.C. } \\
\S \S 1251-1387)\end{array}$ & $\begin{array}{l}\text { To provide a federal framework } \\
\text { for water-quality protection, } \\
\text { delegating specific regulatory } \\
\text { efforts to states for the } \\
\text { development and implementation } \\
\text { of water-quality standards } \\
\text { (303(a)) while maintaining } \\
\text { concurrent federal jurisdiction } \\
(404(t))\end{array}$ & $\begin{array}{l}\text { - The CWA creates a regulatory permitting } \\
\text { system allowing polluting agents to apply } \\
\text { for a permit for any point source pollutant. } \\
\text { - Nonpoint source pollutants from land use } \\
\text { activities such as forestry and agriculture } \\
\text { are exempt from permitting. }\end{array}$ \\
\hline $\begin{array}{l}\text { Endangered } \\
\text { Species Act of } \\
1973 \text { (16 U.S.C. } \S \\
1531 \text { et seq) }\end{array}$ & $\begin{array}{l}\text { To conserve threatened and } \\
\text { endangered species and the } \\
\text { ecosystems on which they } \\
\text { depend (16 U.S.C. } \S 1531 \\
(2)(a)(5)(b))\end{array}$ & $\begin{array}{l}\text { - Once listed, protective measures and } \\
\text { recovery planning efforts are put in place, } \\
\text { intended to protect the species from further } \\
\text { decline. } \\
\text { - Species are given protection from adverse } \\
\text { effects of federal activities through a } \\
\text { consultation process. } \\
\text { - Other protective measures include } \\
\text { restriction on taking of the species through } \\
\text { direct or indirect harm, including habitat } \\
\text { modification. } \\
\text { - Significant civil and criminal penalties can } \\
\text { apply for ESA violations. }\end{array}$ \\
\hline
\end{tabular}


Table 2A. Management action exempted from the Forest Practices Administrative Rules (OAR § 629-600-0100 (53))

\begin{tabular}{ll}
\hline Land use & Exempted action \\
\hline Forestry & Establishment, management, harvest of Christmas trees on land used solely for the production of \\
& Christmas trees. \\
& The establishment, management, or harvest of hardwood timber that is grown on land prepared by \\
& intensive cultivation methods, cleared of competing vegetation for 3 years after tree planting, of a \\
& species marketable as fiber for the manufacturing of paper products, harvested on a rotation 12 years or \\
& less after planting, subject to intensive agricultural practices such as fertilization, cultivation, irrigation, \\
& insect control, disease control.
\end{tabular}

Agricultural - The establishment, management, or harvest of agricultural tree crops (nuts, fruits, seeds, nursery stocks).

- Establishment or management of trees intended to mitigate the effects of agricultural practices on the environment or fish and wildlife resources.

- The development of an approved land-use change after timber-harvest activities have been completed and land-use conversion activities have commenced.

Urban $\quad$ The establishment, management, or harvest of ornamental, street, or park trees within an urbanized area (as defined in ORS § 221.010).

General Any non-commercial timber harvest (e.g., personal uses or other non-commercial harvest). 
Table 3A. Riparian-management standards of the Northwest Forest Plan for federal forest lands

\begin{tabular}{ccc}
\hline \multicolumn{2}{c}{ Stream attributes } & \\
\cline { 1 - 2 } Fish-bearing & Duration & Protective standards: Riparian Reserve width ${ }^{\mathrm{a}}(\mathrm{m})$ \\
\hline $\begin{array}{c}\text { Fish } \\
\text { Non-fish- } \\
\text { bearing }\end{array}$ & All & Two site-potential tree-heights $(\sim 152 \mathrm{~m})$ or $91 \mathrm{~m}$ slope distance, whichever is greatest \\
$\begin{array}{c}\text { Non-fish- } \\
\text { bearing }\end{array}$ & Seasonal & One site-potential tree-heights $(\sim 76 \mathrm{~m})$ or $45 \mathrm{~m}$, whichever is greatest \\
\hline
\end{tabular}

\footnotetext{
${ }^{a}$ Includes standards and guides that direct timber, road, grazing, recreation, minerals, fire and fuels, and other management activities to meet Aquatic Conservation Strategy goals. Allows occasional feathering, salvage, and thinning in areas where harvest actions can be implemented while still meeting Aquatic Conservation Strategy conditions and ecological goals (see USDA and USDI, 1994, Standards and Guidelines C-31).
} 
Table 4A. Riparian-management standards of Oregon State Forest Management Plans for state forest lands

\begin{tabular}{|c|c|c|c|c|c|c|}
\hline \multicolumn{4}{|c|}{ Stream attributes } & \multicolumn{3}{|c|}{ Protective standards: Riparian management area (RMA) } \\
\hline $\begin{array}{c}\text { Fish- } \\
\text { bearing }\end{array}$ & Duration & $\begin{array}{l}\text { Stream } \\
\text { size }\end{array}$ & $\begin{array}{l}\text { Material } \\
\text { transport } \\
\text { potential }\end{array}$ & $\begin{array}{c}\text { No-cut } \\
\text { width (m) }\end{array}$ & Inner RMA (7.6-30 m) & Outer RMA (30-52 m) \\
\hline Fish & All & All & All & 7.6 & $\begin{array}{l}\text { - Manage for mature forest condition, } \\
\text { no management activity where mature } \\
\text { forest conditions exist }\end{array}$ & $\begin{array}{l}- \text { Retain 1) all snags as safety } \\
\text { allows, 2) all dead and downed } \\
\text { material present, } 3 \text { ) at least } 10- \\
45 \text { conifer trees/snags per } 0.4 \\
\text { hectare of RMA } \\
-<10 \% \text { ground disturbance }\end{array}$ \\
\hline $\begin{array}{l}\text { Non-fish- } \\
\text { bearing }\end{array}$ & All & $\begin{array}{l}\text { Large } \\
\text { and } \\
\text { Medium }\end{array}$ & All & 7.6 & $\begin{array}{l}\text { - Manage for mature forest condition, } \\
\text { no management activity where mature } \\
\text { forest condition exist } \\
\text { - Retain 1) any dead and down } \\
\text { material present prior to the operation, } \\
\text { 2) any trees damaged or felled from } \\
\text { yarding activities, 3) additional felled, } \\
\text { girdled or topped trees }\end{array}$ & $\begin{array}{l}\text { - Retain 1) all snags as safety } \\
\text { permits, 2) at least } 10 \text { conifer } \\
\text { trees/snags per } 0.4 \text { hectare of } \\
\text { RMA }\end{array}$ \\
\hline Non-fish & Perennial & Small & $\mathrm{All}^{\mathrm{a}}$ & 7.6 & $\begin{array}{l}\text { - Retain 1) } 15-25 \text { conifer trees/snags } \\
\text { per } 0.4 \text { hectare of RMA, 2) all other } \\
\text { snags as safety permit, } 3 \text { ) all down } \\
\text { and dead material present before } \\
\text { operations } \\
\text { - Within } ~ 150 \text { m of confluence with a } \\
\text { fish-bearing stream, retain all trees } \\
\text { necessary to achieve } 80 \% \text { shade over } \\
\text { channel }\end{array}$ & $\begin{array}{l}\text { - Retain 1) all snags as safety } \\
\text { permits, } 2 \text { ) } 0-10 \text { conifer } \\
\text { trees/snags per } 0.4 \text { hectare of } \\
\text { RMA - whatever amount in } \\
\text { necessary to meet the } \\
\text { combined target for the two } \\
\text { zones ( } 40 \text { trees per } 1.35 \\
\text { hectare) }\end{array}$ \\
\hline
\end{tabular}




\begin{tabular}{|c|c|c|c|c|c|c|}
\hline \multicolumn{4}{|c|}{ Stream attributes } & \multicolumn{3}{|c|}{ Protective standards: Riparian management area (RMA) } \\
\hline $\begin{array}{c}\text { Fish- } \\
\text { bearing }\end{array}$ & Duration & $\begin{array}{l}\text { Stream } \\
\text { size }\end{array}$ & $\begin{array}{l}\text { Material } \\
\text { transport } \\
\text { potential }\end{array}$ & $\begin{array}{c}\text { No-cut } \\
\text { width }(\mathrm{m})\end{array}$ & Inner RMA (7.6-30 m) & Outer RMA (30-52 m) \\
\hline Non-fish & Seasonal & Small & $\begin{array}{l}\text { High } \\
\text { Energy }^{\text {a }}\end{array}$ & 7.6 & $\begin{array}{l}\text { - Retain 1) at least } 15-25 \text { conifer } \\
\text { trees/snags per } 0.4 \text { hectare of RMA, } \\
\text { 2) all other snags as safety permits, } 3 \text { ) } \\
\text { all dead and down material present } \\
\text { prior to operation }\end{array}$ & $\begin{array}{l}\cdot \text { Retain 1) } 0-10 \text { conifer } \\
\text { trees/snags per } 0.4 \text { hectares of } \\
\text { RMA, 2) all snags as safety } \\
\text { permits }\end{array}$ \\
\hline Non-fish & Seasonal & Small & $\begin{array}{l}\text { Potential } \\
\text { Debris } \\
\text { Flow } \\
\text { Track }^{\mathrm{a}}\end{array}$ & 7.6 & $\begin{array}{l}\text { - Retain 1) at least } 10 \text { conifer } \\
\text { trees/snags per } 0.4 \text { hectares of RMA, } \\
\text { 2) all other snags as safety permits, } 3 \text { ) } \\
\text { all dead and down material present } \\
\text { prior to operation }\end{array}$ & $\begin{array}{l}\text { - Retain trees and snags } \\
\text { sufficient to meet landscape } \\
\text { management strategy targets }\end{array}$ \\
\hline Non-fish & Seasonal & Small & Other $^{a}$ & $0^{\mathrm{b}}$ & $\begin{array}{l}\text { - Retain 1) at least } 10 \text { conifer } \\
\text { trees/snags per } 0.4 \text { hectares, 2) all } \\
\text { other snags as safety permits, 3) all } \\
\text { dead and down material present prior } \\
\text { to operation }\end{array}$ & $\begin{array}{l}\text { - Retain trees and snags } \\
\text { sufficient to meet landscape } \\
\text { management strategy targets }\end{array}$ \\
\hline
\end{tabular}


Table 5A. Riparian-management standards of Oregon's Forest Practices Administrative Rules for private forest lands

\begin{tabular}{|c|c|c|c|c|c|c|}
\hline \multicolumn{4}{|c|}{ Stream attributes } & \multicolumn{3}{|c|}{ Protective standards: Riparian management areas } \\
\hline $\begin{array}{c}\text { Fish- } \\
\text { bearing }\end{array}$ & Duration & $\begin{array}{l}\text { Stream } \\
\text { size }\end{array}$ & $\begin{array}{l}\text { Domestic } \\
\text { water Use }\end{array}$ & $\begin{array}{c}\text { No cut } \\
\text { width }(\mathrm{m})\end{array}$ & $\begin{array}{c}\text { RMA } \\
\text { width (m) }\end{array}$ & Requirements \\
\hline Fish & All & Small & All & 6 & 15.2 & $\begin{array}{l}\text { - Written plan for operations within } 30 \mathrm{~m} \\
\text { - Sets basal area standards for RMA } \\
\text { - Retain 1) all trees leaning over stream, 2) snags and } \\
\text { down wood in channel, 3) enough live conifers to meet } \\
\text { RMA (hardwoods allowed in some circumstances), 4) } \\
\text { live conifers/area to ensure shading }\end{array}$ \\
\hline Fish & All & Medium & All & 6 & 21.3 & $\begin{array}{l}\text { - Written plan for operations within } 30 \mathrm{~m} \\
\text { - Sets basal area standards for RMA } \\
\text { - Retain 1) all trees leaning over stream, 2) snags and } \\
\text { down wood in channel, 3) enough live conifers to meet } \\
\text { RMA (hardwoods can be used sometimes), live } \\
\text { conifers/area to ensure shading }\end{array}$ \\
\hline Fish & All & Large & All & 6 & 30.5 & $\begin{array}{l}\text { - Written plan for operations within } 30 \mathrm{~m} \\
\text { - Sets basal area standards for RMA } \\
\text { - Retain 1) all trees leaning over stream, 2) all understory } \\
\text { veg within } 3 \mathrm{~m}, 3 \text { ) snags and down wood in channel, 4) } \\
\text { enough live conifers to meet RMA (hardwoods allowed in } \\
\text { some circumstances), 4) live conifers to ensure stream } \\
\text { shading }\end{array}$ \\
\hline \multirow{3}{*}{$\begin{array}{l}\text { Non- } \\
\text { fish- } \\
\text { bearing }\end{array}$} & All & Small & Yes & 6 & 6 & $\begin{array}{l}\text { - Written plan for operations within } 30 \mathrm{~m} \\
\text { - Sets basal area standards for RMA }\end{array}$ \\
\hline & & Medium & Yes & 6 & 15.2 & $\begin{array}{l}\text { - Retain 1) all trees leaning over stream, 2) all understory } \\
\text { veg within } 3 \mathrm{~m}, 3 \text { ) snags and down wood in channel, 4) }\end{array}$ \\
\hline & & Large & Yes & 6 & 21.3 & $\begin{array}{l}\text { enough live conifers to meet RMA (hardwoods can be } \\
\text { used sometimes), 5) enough live conifers to ensure stream } \\
\text { shading }\end{array}$ \\
\hline
\end{tabular}




\begin{tabular}{|c|c|c|c|c|c|c|}
\hline \multicolumn{4}{|c|}{ Stream attributes } & \multicolumn{3}{|c|}{ Protective standards: Riparian management areas } \\
\hline $\begin{array}{c}\text { Fish- } \\
\text { bearing }\end{array}$ & Duration & $\begin{array}{l}\text { Stream } \\
\text { size }\end{array}$ & $\begin{array}{l}\text { Domestic } \\
\text { water Use }\end{array}$ & $\begin{array}{c}\text { No cut } \\
\text { width }(\mathrm{m})\end{array}$ & $\begin{array}{c}\text { RMA } \\
\text { width (m) }\end{array}$ & Requirements \\
\hline $\begin{array}{l}\text { Non- } \\
\text { fish- } \\
\text { bearing }\end{array}$ & All & Large & No & 6 & 21.3 & - Retain 30 live conifers per 0.6 hectare \\
\hline $\begin{array}{l}\text { Non- } \\
\text { fish- } \\
\text { bearing }\end{array}$ & All & Medium & No & 6 & 15.2 & $\begin{array}{l}\text { - Retain } 10 \text { live conifers per } 0.45 \text { hectare, must be at least } \\
20 \mathrm{~cm} \mathrm{DBH}\end{array}$ \\
\hline $\begin{array}{l}\text { Non- } \\
\text { fish- } \\
\text { bearing }\end{array}$ & Perennial & Small & No & 0 & 3.3 & $\begin{array}{l}\text { - Retain non-merchantable conifer trees }<15 \mathrm{~cm} \text { DBH } \\
\text { within } \sim 3 \mathrm{~m} \text { of high water mark. }\end{array}$ \\
\hline $\begin{array}{l}\text { Non- } \\
\text { fish- } \\
\text { bearing }\end{array}$ & Seasonal & Small & No & 0 & 0 & $\begin{array}{l}\text { - Specific water-quality protection measures may apply } \\
(\text { OAR } \S 629-640-0200)\end{array}$ \\
\hline
\end{tabular}

